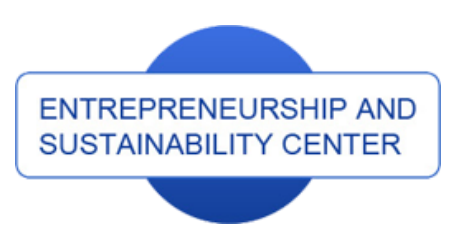

Publisher

http://jssidoi.org/esc/home enterprise

europe

network

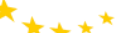

Business Support on Your Doorstep

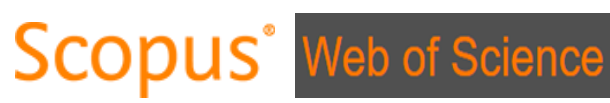

\title{
INNOVATION ACTIVITIES OF GAZELLES IN BUSINESS SERVICES AS A FACTOR OF SUSTAINABLE GROWTH IN THE SLOVAK REPUBLIC**
}

\author{
Dana Benešová ${ }^{1}$, Viera Kubičková ${ }^{2}$, Anna Michálková ${ }^{3}$, Monika Krošláková ${ }^{4}$ \\ 1,2,3,4 University of Economics in Bratislava, Faculty of Commerce, Department of Services and Tourism, \\ Dolnozemská cesta 1, Bratislava, Slovak Republic,
}

E-mails: ${ }^{1}$ dana.benesova@euba.sk $;{ }^{2}$ viera.kubickova@euba.sk, ${ }^{3}$ anna.michalkova@euba.sk, ${ }^{4}$ monika.kroslakova@euba.sk

Received 20 May 2017; accepted 15 December 2017; published 30 March 2018

\begin{abstract}
Gazelles create greater share of new jobs in comparison with other businesses operating on the market. These are young businesses of various sizes, but mainly small businesses. They generate a high rate of growth of production within a short time, which is based on the use of innovation, they are also the bearers of innovation. They are characterized by effective use of creativity and human resource capacities. They may be found in all sectors of economy, but to the greatest extent in the services sector and within that sector mainly in business services characterized by high knowledge intensity, high dynamics and continuous growth in employment. Gazelles of business services in the Slovak Republic intensively use all types of innovation. Management ability to optimize innovative processes according to needs of the enterprise seems to be of importance. Human resources and performance is considered to be the most important area of innovation influence. With its innovative activity they act as the accelerator of economy and changes in the thinking and culture of both enterprises, as well as the whole company toward sustainable growth.
\end{abstract}

Keywords: innovation, gazelles, fast-growing companies, business services, knowledge-intensive services, performances, sustainable growth

Reference to this paper should be made as follows: Benešová, D.; Kubičková, V.; Michálková, A.; Krošláková, M. 2018. Innovation activities of gazelles in business services as a factor of sustainable growth in the Slovak Republic, Entrepreneurship and Sustainability Issues 5(3): 452-466. https://doi.org/10.9770/jesi.2018.5.3(3)

JEL Classifications: O31, L2

\footnotetext{
* Grant project of the Ministry of Education, Science, Research and Sport of the Slovak Republic KEGA 027EU-4/2016 Textbook Business Fundamentals. Project period: 2016-2017
} 


\section{Introduction}

Young, rapidly growing businesses called gazelles form a significant subset of entrepreneurial entities with high growth (Eurostat-OECD, 2007; OECD, 2012; Krošláková et al., 2015). The fast-growing companies reach more than a $20 \%$ revenues or employment increase during the period of three consecutive years, but their age from the establishment does not exceed five years (Ahmad, 2006; Eurostat-OECD, 2007; OECD, 2015).

Statement that small and medium-sized enterprises create jobs was mentioned for the first time by David Birch in his work (1979). Birch assumed that new jobs are created mainly in small and medium-sized enterprises, in particular in those newly established. Birch examined this hypothesis with his team (1997) in the US, and found that on average two thirds of all jobs are created by small and medium-sized enterprises. Other authors (Birch et al, 1997; Moreno, Casillas, 2000; 2007) define gazelles as companies which are able to generate high growth rates in very short time periods. According to Eric P. Canab (1998), gazelle is a company, which is experiencing an extended period of rapid growth.

Australian research of the environment of fast-growing companies - gazelles - focused on identifying differences and specifics operating at the stage of establishment in enterprises - gazelles and in enterprises - non-gazelles (Cunneen and Meredith 2007). Results show the ability of gazelles to risk, to act independently, intuitively and aggressively in the competition, while being able to benefit from networking. On the other hand, they are concentrated on the support of human resources quality and creativity development.

Gazelles bring new products to the market and they are looking for new markets. They focus on the efficiency of production and business processes, they use advanced information technologies, employ skilled workers, have experienced management and successfully established themselves in the global market. (Barnard et al., 1998). Most of them are companies that are the pioneers in structural changes in their field and have a developed corporate culture based in particular on innovations and search for new opportunities for asserting themselves on the market, or on the growth of market share. They introduce mainly new ideas and innovation in their processes, therefore it may be presumed that these companies could be the biggest innovators in the market (Stone and Badawy 2011). The ability to promote innovation is a more important factor of growth in the case of these enterprises than their small size (Henrekson and Johanson 2010). Under Stone and Badawy (2011), it is possible to combine a beginning firm and a gazelle, because the company, which fills the gap in the market through innovation, has a huge projection of further growth. Gazelles exist in all sectors, primarily in services (Henrekson, Johanson 2010). They focus mainly on knowledge production, science and research (OECD, 2013), which is characteristic for sub-sector of business services. Experts agree that many enterprises of business services were founded as quickly growing businesses or gazelles. Therefore the aim of the article was to identify the importance of using intangible assets by enterprises of business services, to find out the innovative ability of gazelles of business services operating on the market in the Slovak Republic, the impact of introduced innovations on their business activities, as well as the socio-economic contribution to sustainable growth.

\section{Literature Review}

Knowledge production of business services. The most dynamic and the most productive small and mediumsized enterprises belonging into the services sector are services demanding on knowledge (knowledge-intensive services - KIS). Diffusion of knowledge production in the processes of other enterprises supports the growth and competitiveness of the whole economy. As producers or providers of new knowledge they strengthen the innovative processes in manufacturing and service enterprises, their activity, therefore, goes beyond the borders of the service sector. 
The International Journal

ENTREPRENEURSHIP AND SUSTAINABILITY ISSUES

ISSN 2345-0282 (online) http://jssidoi.org/jesi/

2018 Volume 5 Number 3 (March)

http://doi.org/10.9770/jesi.2018.5.3(3)

Several foreign and domestic authors addressed the characteristics of knowledge-intensive services in the last decade, among them Wolfl, Bryson, Daniels, Andersen, Miles, Haataja, Okkonen, and others. For example, according to Haataja and Okkonena (2004) knowledge-intensive services are characterized by the following: knowledge is highly valued and has a strong position as the input source, it is primarily based on professional skills, it is source of knowledge for its users or it is used as input in order to develop knowledge of its clients, between the client and the supplier. When the knowledge is generated and passed on, there is an intensive interaction.

Many studies associate KIS not only with productivity growth in other enterprises, but also indicate that they have common characteristics with manufacture based on high technology (High technology Manufacturing) (OrtegaArgilés et al., 2009). Production and service enterprises of KIS show many common signs, in particular, in their innovation processes, such as the interaction with suppliers and in innovation intensity. (De Jong and Marsili 2006).

Externalization process, taking place in the economies in the last few decades, separated several activities as information and computer services, legal, accounting, marketing, personnel services and others from large enterprises. Independent entities were thus created that established themselves on the market, as closely specialised small and medium-sized enterprises called business services. Production of vast majority of them is based on knowledge, and thus in general they are knowledge-intensive. In practice, there are as many types of knowledge-intensive business services (KIBS) as there is a lot of knowledge, so naturally there is a great diversity between their development, structure and purpose.

According to Miles et al. (1995) these are services, the result of which is the creation, accumulation or dissemination of knowledge. They are based on professional skills, they are primary sources of information, and make up new knowledge provided to their customers, and their production brings a competitive advantage and is mainly directed at enterprises. Toivonen (2004) also claims that these services are provided by enterprises for other enterprises or the public sector, where professionalism plays a particularly important role. Also other authors, such as Koch and Strotmann (2008) state similarly ..."these are highly application-oriented services where knowledge plays an important role." ..."KIBS are largely based on professional knowledge, they are closely specialised in the field, their output is an intermediate product, not the final product" (Hertog, 2000).

In view of the fact that they provide services of intangible nature, a high degree of interaction is necessary and adaptation of their individual needs, which requires close and intensive cooperation with customer's company. Without the cooperation of the customer with the KIBS enterprise, it is not possible to obtain the so-called "hidden" knowledge about customer's company, which is an essential element in the creation of provided human service.

Many authors highlight not only the dependence between KIBS, innovation and the performance of the whole economy (e.g. Hipp, 1999; Tomlinson, 1999; Aslesen and Isaksen, 2007), but also connection of innovative activities, knowledge mediated by KIBS with industry, science and customers (Czarnitzki and Spielkamp, 2003, Drieniková and Kašt’áková 2016).

It may be summarized that the knowledge-intensive services of business services are characterised by high knowledge intensity and a relatively high capital and innovative intensity, high degree of specialisation and interaction. Their production is directed mainly at intermediate consumption, their activity consists in providing knowledge and skills to other enterprises. 


\section{The International Journal}

ENTREPRENEURSHIP AND SUSTAINABILITY ISSUES

ISSN 2345-0282 (online) http://jssidoi.org/jesi/

2018 Volume 5 Number 3 (March)

http://doi.org/10.9770/jesi.2018.5.3(3)

Innovation as a factor of dynamic and sustainable economic growth. Systematization of knowledge on business determinants of growth, in particular from the knowledge-based company, confirms significance of innovations for the economic growth of enterprises and rapidly growing firms, gazelles included. Innovation effect, however, may vary due to heterogeneity of enterprises and typology innovation. Of course, these are affected by a range of factors from the internal business environment, as well as from the external environment.

Small companies show higher growth potential, as is the average, but growth is conditional upon the ability to gain external sources of financing and access to foreign markets (Becchetti, Trovato, 2002). A research of 407 Swedish small and medium-sized enterprises was conducted in the years 2006 - 2009, while the enterprises were differentiated according to the achieved economic growth. It has been demonstrated that enterprises with a high growth achieve a higher profitability, increased the number of employees and have experienced higher market share on the local, national and international markets in comparison with the companies with low growth. The result was accompanied by the following significant element: higher share of new products to the achieved sales (Grundström et al., 2012). Focus on innovation is considered to be the crucial element of growth strategy of market leaders by the author Laforet (2010). Within the meaning of innovation impact on the economic growth, it is necessary to add considerations on diversity of impact of the various types of innovation on business growth. If product innovations give rise to an increase in the number of personnel, process innovations have an adverse effect, which is manifested by reducing human labour per unit of output.

Performed studies have shown that high investments in research and development and high innovation level may not lead to an increase in their profits, but that the fast-growing companies tend to be more innovative (Coad, 2009; Storey, Greene, 2010). Instead of expensive and risky scientific-research projects, small and medium-sized enterprises should focus on the development of products and markets, keep an up-to-date knowledge of new technologies and competition, as well as be able to expand their own customer base. In order to achieve a longterm sustainable growth this may be implemented by either introducing new products to an existing market, or by acquisition of new markets by placing existing products (Dobbs, Hamilton, 2007; Bessant, Tidd, 2011). However, enterprises are more focused on product than process innovation (Coad, 2009; Bessant, Tidd, 2011) and specialise in technological expertise, the product range with the aim of closing the market gaps (Bessant, Tidd, 2011). The type of innovation introduced by the company is not so crucial. Raymond and St-Pierre (2010) confirmed that even if innovation of products and processes are often examined separately as completely different, these two types of innovation are connected during the implementation of the innovation process into the enterprise value chain (Fuller, Matzler, 2007).

Innovation and development of products are more formalised in large enterprises (Cooper, Kleinschmidt, 1995), while in the environment of small and medium-sized enterprises they affect the whole corporate structure (Strerlacchini, 1999). Small enterprises usually use one of the forms of open innovation, which may vary in the light of the degree of cooperation, in particular if the enterprise does not have enough internal resources for innovation or its management. The extent of openness depends on with whom the enterprise cooperates. Openness is defined either by supply absorption capacity (inside-out), or consumer absorption capacity (outside-in) (Newey, 2010). It is likely that enterprises with market orientation grow faster, because they are able to expand their products. (Verhees, Meulenberg, 2004; Capelleras, Greene, 2008).

Mason (2009) states that innovative enterprises grow twice as fast as compared with companies that hardly innovate. The characteristics of the most rapidly growing firms in Scotland equal to orientation on knowledge and innovation. The author states that the functional attributes of fast-growing companies are high quality production outputs, knowledge of workers about the market and consumers, and a high level of internationalisation. Positive and significant association with productivity is also mentioned by further studies, according to which companies with more intangible assets have a higher precondition to achieve higher productivity. At the heart of these studies 
The International Journal

ENTREPRENEURSHIP AND SUSTAINABILITY ISSUES

ISSN 2345-0282 (online) http://jssidoi.org/jesi/

2018 Volume 5 Number 3 (March)

http://doi.org/10.9770/jesi.2018.5.3(3)

are: expenditure on research and development and progressive technologies and equipment, management procedures, corporate strategies, the talent of managers, information technology, employees, quality, product innovation, organizational structure, and the like.

Promoting innovation in services is determined by specific nature of services and factors shaping the offer of services. Key factors are the quality of human factor and the use of techniques and technologies, including the ICT. Rapid spread of the internet and mobile connection forced the marketing experts to focus on speed, planning and electronic access, and thereby accelerate the process of production or sale of services.

A critical moment in production of services is engagement of the client in the process of the provision of services and establishing a relationship with the customer. Also marketing and delivery of the service at the appropriate time is an important moment assessed by the customer. Establishing a relationship with the customer through the internet and mobile networks is a rapidly growing trend, progress in IT allows implementation of new technological innovations in services and supports creation of new ideas.

Several studies examined the strategic role of information technology (IT) in innovations. These have confirmed that IT significantly facilitate innovation of services in a number of sectors (such as health, financial services, technical services, in consulting, in the field of management) (Guo, Chao, 2014; Hilkevics, Hilkevica, 2017; Luhn et al., 2017). Froehle and Roth (2004) indicate five ways explaining diversity of contacts with the customer mediated by technology or a customer relationship in relation to technology. These support a range of relations between the provider and the client - from technology supporting direct contact with the customer to the selfservice technology. However, accumulation of key components of the intangible assets is a long-term process in an environment of services, because they are based on the trust of the client to the company with a longer history and better reputation. Despite the multiple statements on positive impact of innovation on productivity and economic growth of service enterprises, there are also ambiguous or negative statements in different sources. Several studies (Brynjolfsson, 1993; Wilson, 1993, 1995) have shown that there is no relationship between information and communication technologies and the enterprise performance, here we speak of the so-called technological or information paradox. Solow (1987) stated that the computer age can be seen everywhere, but not in statistical evaluations of productivity.

Similar doubts can also be expressed in relation to another types of innovation (product, organizational, marketing). Generally, the innovative effects come with time-delay, especially in an environment of services production, which has an inseparable and intangible nature and consumption is based on experience or trust. Therefore, it is justified that the positive impact of innovations on performance and economic growth is difficult to identify.

\section{Methods}

Meeting of the specified objective has been achieved through scientific methods, namely analysis of secondary sources, synthesis of relevant findings and subsequent induction in order to establish the innovative capacity of gazelles of business services in the Slovak Republic. Verifying the impact of innovations introduced in the business processes of the gazelles of business services was carried out by the questionnaire. Statistical and mathematical methods of correlation and regression analysis in Excel and Gretl were used to determine the productivity and employment in business services. In order to achieve the objective, we have set 1 hypothesis and 4 research questions, which are answered in the part Results and discussion. 
The secondary research was based on the study and processing of domestic and foreign theoretical and statistical sources, as well as research studies, in particular in the databases ProQuest, Ebsco Host, Scopus, Web of Knowledge, OECD, Eurostat, Statistical Office of the Slovak Republic.

The dependence of selected factors of economic growth was expressed by means of the correlation coefficient - Pearson correlation coefficient $(r)$ and the chart of dependencies was used for illustration of results. The determination coefficient $\left(r^{2}\right)$ served for the evaluation of variability of the estimated linear regression model. We were interested in the equation of regression line in case of the regression method, which is as follows (1):

$$
\hat{y}=b_{0}+b_{1} X
$$

The Power indicator productivity (gross value added per employee) is in the position of independent variable (x) and employment acts as dependent variable (y). Service enterprises were the object of examination under the NACE rev. classification 2 in the section J, L, M, N.

The primary research was conducted in the period 11/2015 - 03/2016 by means of an interview survey. Database of enterprises was generated from two statistical sources - the Statistical Office of the Slovak Republic and the company FinStat. Combination of these two sources has been chosen in order to reach the complexity of data conditioned by their availability. In 2015, the Statistical Office of the SR made the identification of gazelles in the Slovak Republic available for the first time, showing data from 2012 and 2013. Information on gazelles in the SR for the year 2014 have been supplemented from the database of FinStat company. During the observed three-year period, 342 gazelles in total have been identified within the Slovak economy of Slovakia - in the services sector. Section M Professional, scientific and technical activities was represented by $22 \%$ share, Section J Information and communication was represented by $12 \%$ share and Section N Administrative and support services by $3 \%$ share. Initial database of enterprises was made of the group of KIBS enterprises (NACE rev. 2 J 62 Computer programming, consultancy and related services, J 63 Information Services, M 70 Company management, consultancy in the field of management, M 72 Scientific research and development, M73 Advertising and market research) meeting the criteria of gazelles, with the total number of 112 enterprises.

Intensity of introduced innovation impact in business services is expressed as a weighted arithmetic mean of individual business response values in the primary research, using the Likert scale, scoring 0-3 (0 - no impact, 1 slight impact, 2 - significant impact, 3 - very significant impact). The value interval of individual elements intensity (specified effects) in the enterprises was $0 ; 3$.

\section{Results and discussion}

Hypothesis 1 Productivity growth has no effect on employment growth in the Slovak business services. 
The International Journal

ENTREPRENEURSHIP AND SUSTAINABILITY ISSUES

ISSN 2345-0282 (online) http://jssidoi.org/jesi/

2018 Volume 5 Number 3 (March)

http://doi.org/10.9770/jesi.2018.5.3(3)

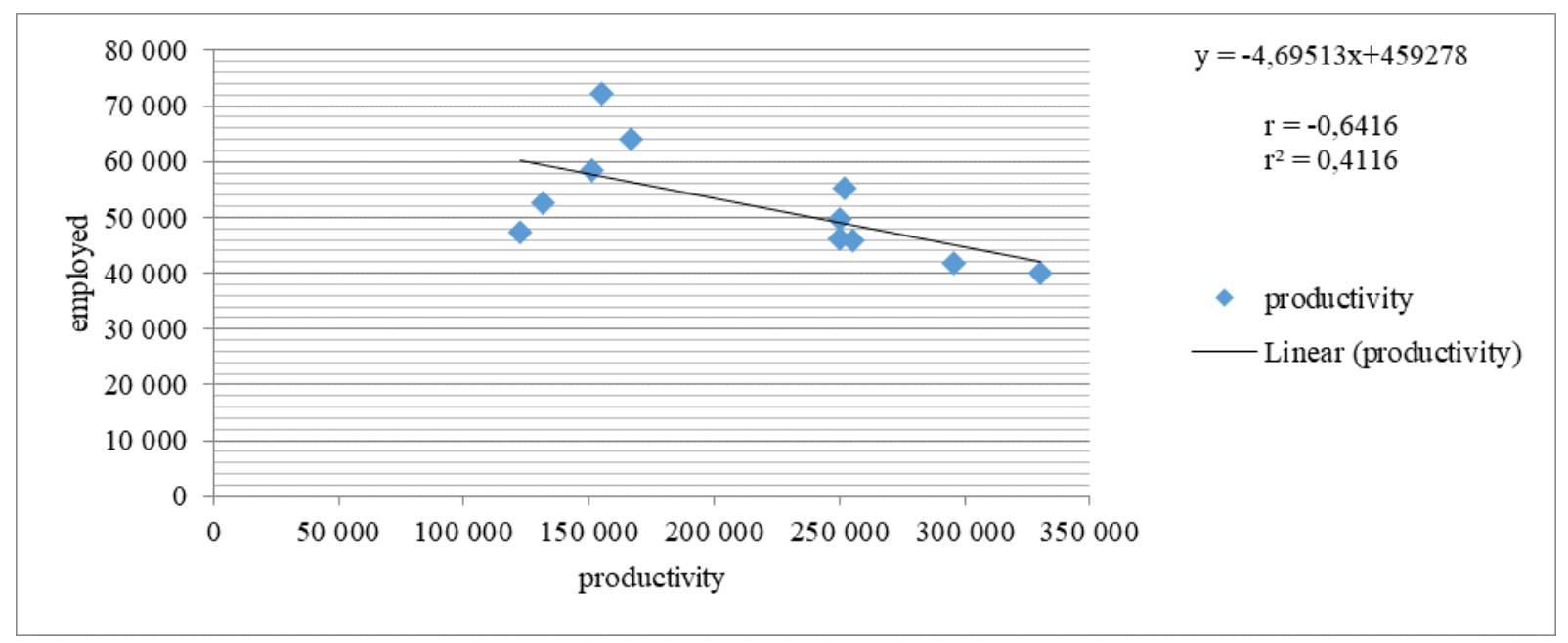

Fig. 1. The relationship of productivity growth and employment in business services in the Slovak Republic in the years $2005-2015$

Source: Own processing according to Eurostat data

Based on correlation analysis $(r-0,6416)$ and regression analysis $\left(r^{2} 0,4116\right)$ we are adopting hypothesis 1 (Figure 1). There is a moderately strong indirect linear dependency between productivity growth and employment in business services. This means that if productivity in enterprises of business services rises, the number of workers must not. Even though there was a continuous growth of employment and performances measured by volume of gross added value (see Figure 2) in the sub-sector of business services in the last decade, the analysis confirmed significant importance of using the capacity of available human resources, as well as intangible assets, such as innovations and ICT.

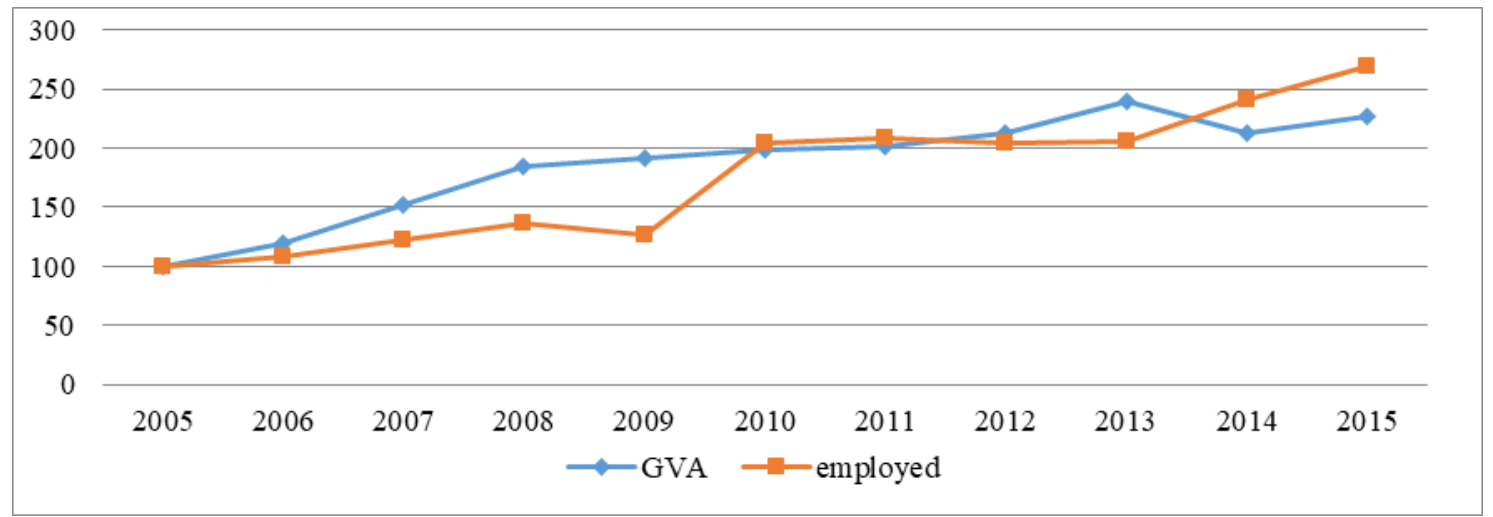

Fig. 2. Development of gross added value and employment in business services in the Slovak Republic in the years 2005-2015 (in \%, 2005 $=100 \%$ )

Source: Own processing according to Eurostat data

Research Question 1: Which sector of economy has the most gazelles in selected countries and in the Slovak Republic? 


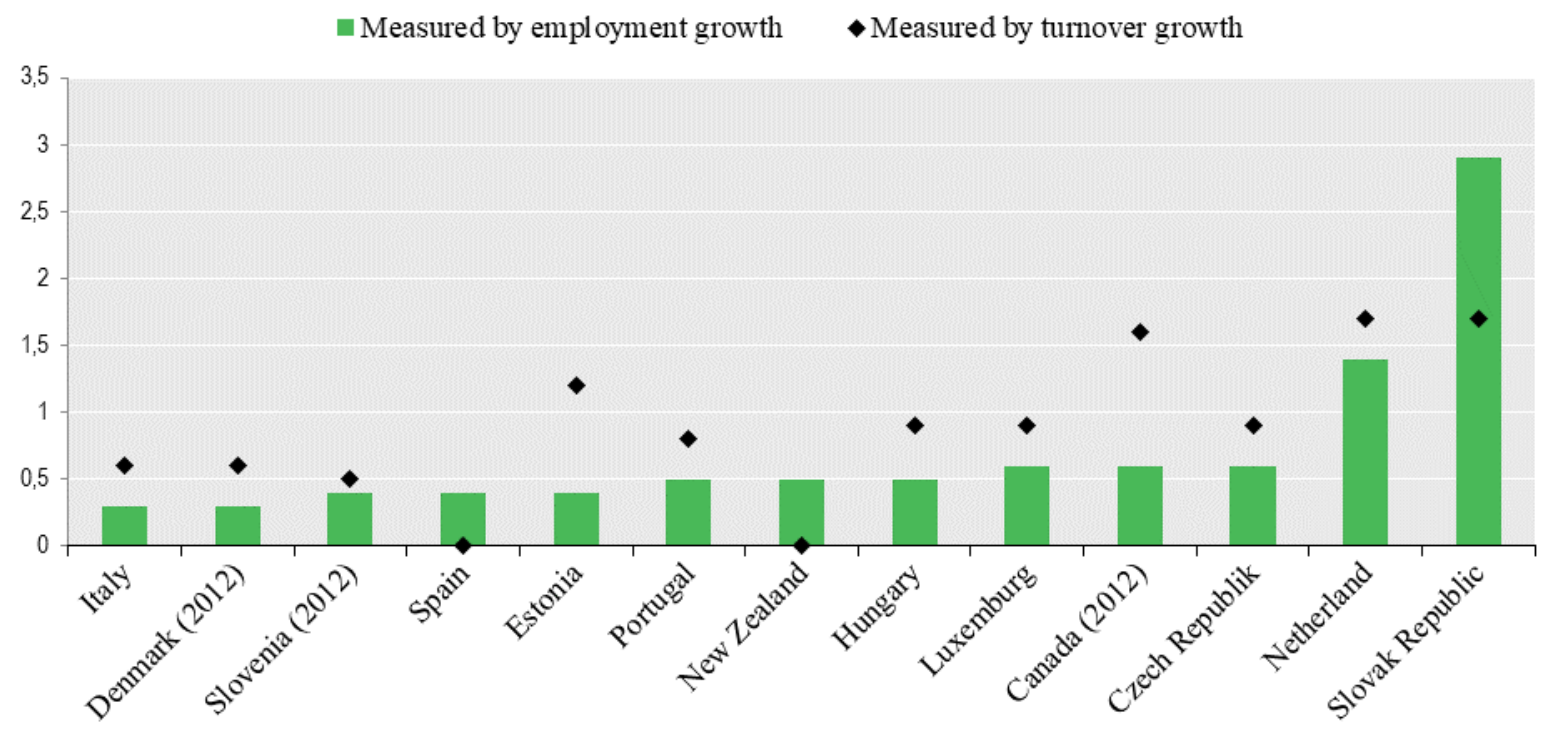

Fig. 3. The share of gazelles in the number of enterprises with 10 and more employees according to the criterion of increase in turnover and employment in selected OECD countries in $2013(\%)$

Source: Own processing according to OECD data, 2015.

The most important share in the total number of enterprises was reached by the gazelles in Slovakia (2.9\%) and the Netherlands (1.4\%) according to the employment increase indicator. Gazelles in Denmark and Italy had the lowest representation $(0.3 \%$ ) (Figure 3). According to the indicator of turnover increase, the share of gazelle representation in all observed countries is higher. Slovak and Dutch gazelles also had the highest share $(1.7 \%)$ in this assessment, the lowest representation of gazelles was again recorded by Denmark and Italy (0.6\%) (Figure 4).

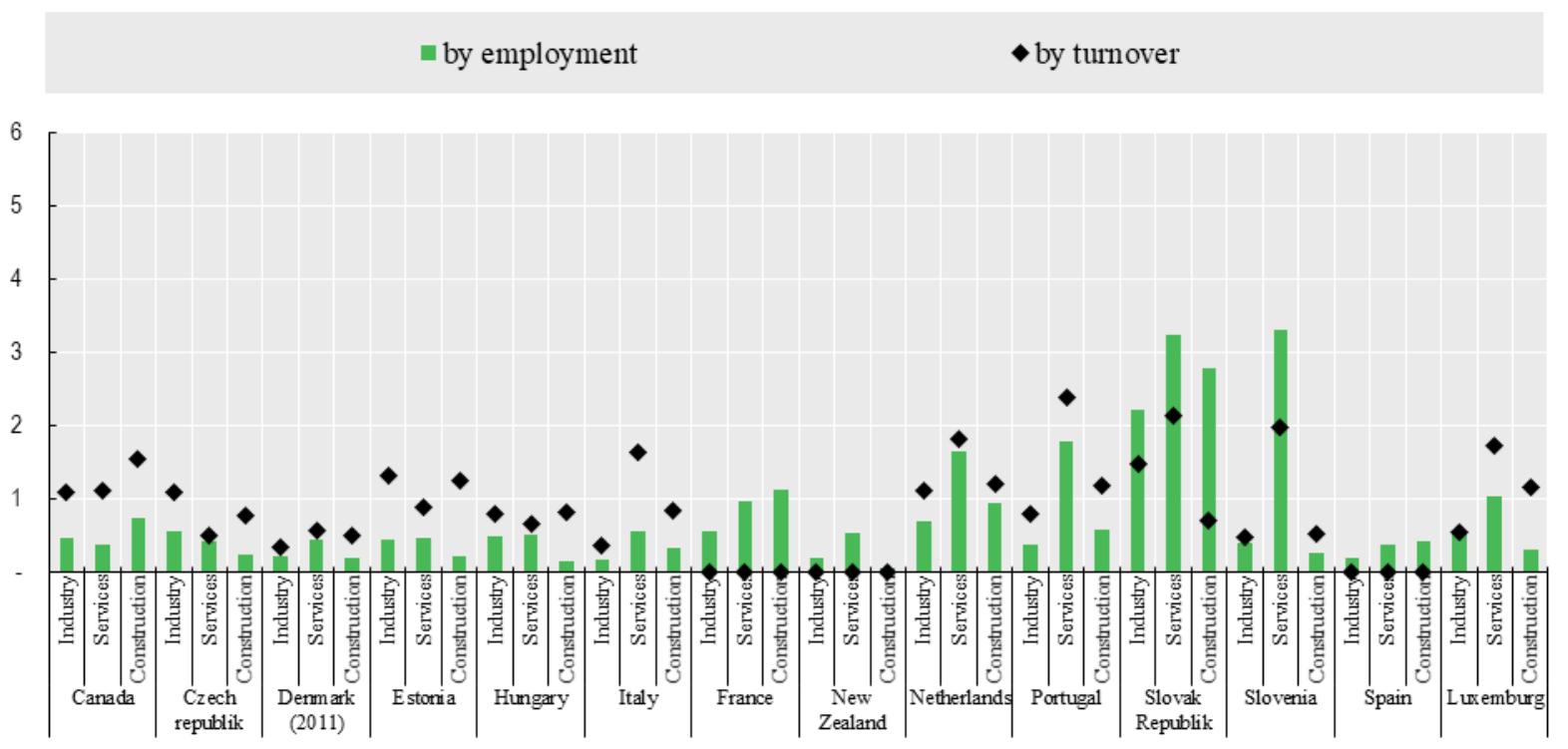


Fig. 4. The share of gazelles in the number of enterprises with 10 or more employees in the various sectors of economy according to the criterion of increase in turnover and employment in selected OECD countries in $2013(\%)$

Source: Own processing according to OECD data, 2015.

Gazelles in the Slovak Republic thus form an above average share in the group of all active enterprises with 10 and more employees within economy. Their participation in different sectors (construction, industry, services) is higher than the average of selected countries. Based on the observation of sectoral structure of Slovak gazelles, we can say that these are characterised by dominant existence in the services sector according to both criteria increase in turnover and employment $(2.14 \%, 3.23 \%)$.

Research Question 2: Does innovation affect the economic growth of gazelles of business services?

Table 1. Innovation influence upon the growth of turnover/employment in gazelles of business services in the SR

\begin{tabular}{|l|l|}
\hline & Gazelles of business services \\
\hline Yes & $50.0 \%$ \\
\hline No & $2.8 \%$ \\
\hline Not able to judge & $47.2 \%$ \\
\hline
\end{tabular}

Source: Own research, 2016.

Gazelles are aware of the innovation effects upon their economic growth (Table 1). The fact of low involvement can be described as problematic and subsequently also the state of knowledge on innovation effects in gazelle managements of business services, when businesses cannot assess the impact of innovation on their growth. Enterprises of business services have rejected the link between innovation and economic growth only in $2.8 \%$. A relatively high value achieved in the option "not able to judge" indicates a relatively weak initiative of business managements to analyse the benefits of innovation. Taking into account the criterion of geographical origin of enterprises brought the knowledge of the highest awareness of economic benefits of innovation in foreign gazelles of business services.

Research Question 3: Application of which innovation is the most frequent? 


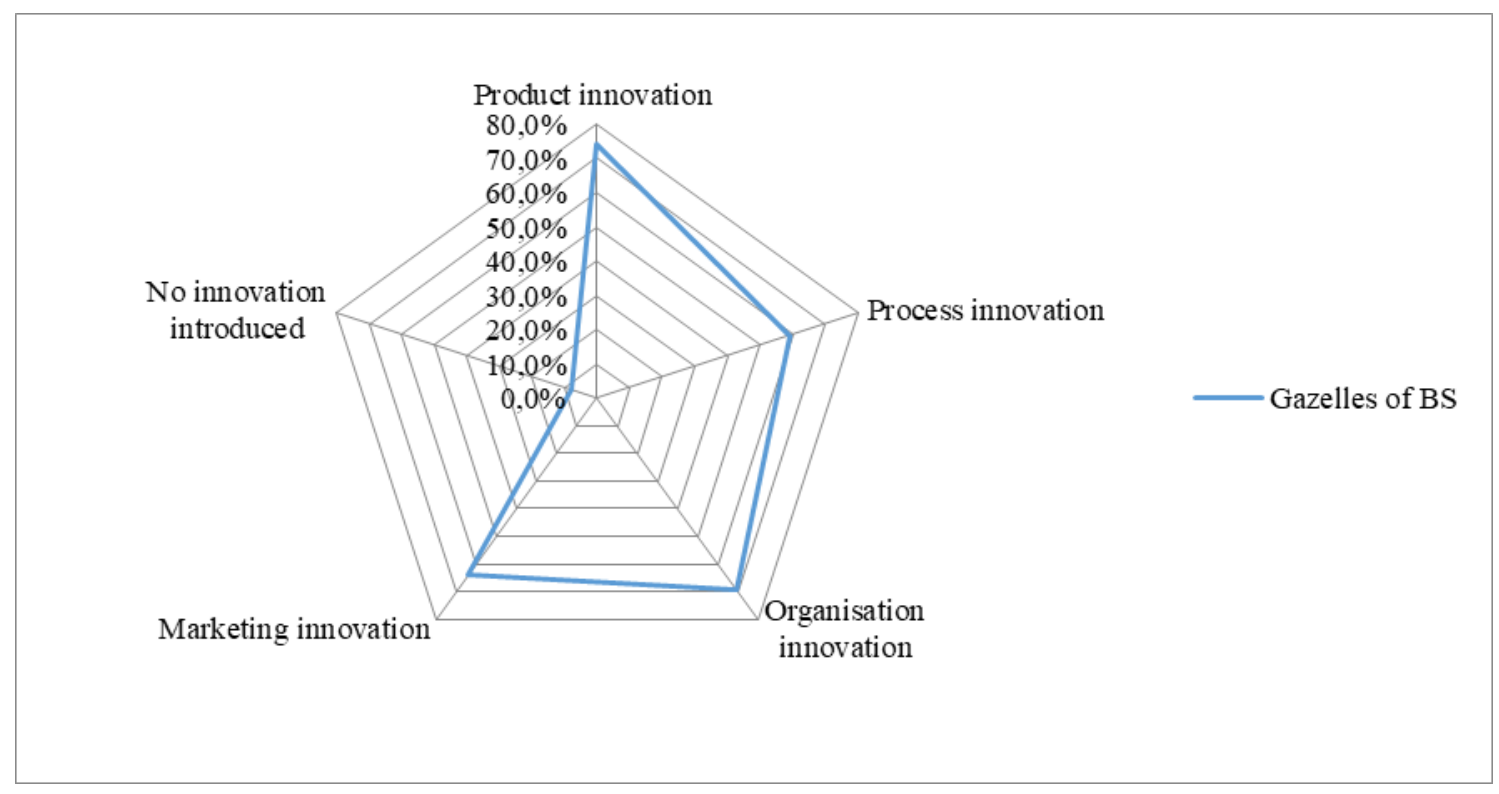

Fig. 5. Application of innovation in gazelles of business services in the Slovak Republic

Source: Own research, 2016.

For all types of innovation, the situation is very similar, as most gazelles of business services introduce the nontechnological, as well as technological innovation (Figure 5). The presumption of priority use of nontechnological innovation in gazelles of business services in connection with the statements on the application of innovation in services was not confirmed. Technological innovations are a used source of gazelle's growth, in foreign enterprises in full extent (100\% of enterprises), all the observed foreign gazelles introduced process innovations.

As far as possible, the gazelles of business services focus on product innovation (74.4\%). This result is influenced by individual nature of production according to the specific needs and tasks of clients (consultancy, research, etc.). On the basis of that it can be concluded that more divisions of business services carry out an estimated number of product innovations, than the number of tasks from clients. Priority type of product innovation for gazelles of business services are innovations partly or totally new for the company.

Gazelles of business services having a high knowledge intensity, high degree of team work, production requiring interactivity with customers are implemented by IT in particular in internal business processes. This results from the need to optimize team cooperation and the exchange of information between employees, exchange of documents with suppliers and customers. Therefore more than $40 \%$ of gazelles of business services introduced a mobile employee access to information systems of the enterprise, one half implemented a CRM system for analytical and marketing purposes, and the electronic exchange of documents with suppliers is used by a quarter of gazelles of business services.

Individual and specialised nature of production of business services determines the strong concentration on organizational innovation, which were introduced by gazelles of business services within the extent of $69.2 \%$. In this context, it is important that the products of business services are the result of knowledge-intensive production, they are implemented through projects and frequent product innovation requires changes of competences and performance of workers. The workers are tasked with the requirement of flexibility in work assignments and 
The International Journal

ENTREPRENEURSHIP AND SUSTAINABILITY ISSUES

ISSN 2345-0282 (online) http://jssidoi.org/jesi/

2018 Volume 5 Number 3 (March)

http://doi.org/10.9770/jesi.2018.5.3(3)

performances. Gazelles of business services innovate intensively in areas such as outsourcing, redesign of jobs, IT skills, cooperation with enterprises and universities.

The most often used type of introduced marketing innovation in all observed gazelles is social marketing, direct marketing (e-mail marketing, multi-channel communication with customers), but also experiential marketing (event marketing); also the organisation of conferences, seminars and workshops. As a consequence of knowledge production of observed gazelles toward the intermediate consumption, a higher frequency of marketing focused on professional target customer segment was established.

\section{Research Question 4: Which areas are most intensively affected by innovation?}

Table 2. Intensity of implemented innovations impact in gazelles of BS in the SR.

\begin{tabular}{|l|r|}
\hline Effects of innovations & \multicolumn{1}{|c|}{ Gazelles of business services (\%) } \\
\hline Increased revenue from sales & 14.25 \\
\hline New clients & 16.25 \\
\hline Popularity, good name of enterprise & 14.00 \\
\hline Increased customer satisfaction & 13.75 \\
\hline Integrated customer information & 10.25 \\
\hline Creating long-term relationship with customers & 12.50 \\
\hline Customizing the offer to the customer & 12.25 \\
\hline Satisfaction of employees & 11.50 \\
\hline Employee loyalty & 5.25 \\
\hline Overview of business flows & 7.50 \\
\hline New partners & 6.75 \\
\hline Entry into the scientific-research project & 6.25 \\
\hline Greater efficiency of work - productivity & 11.75 \\
\hline Obtaining a quality certification & 2.00 \\
\hline Reduction of environmental burden & 1.25 \\
\hline Formation of scientific-research unit & 3.75 \\
\hline
\end{tabular}

Source: Own research, 2016.

Intensity of introduced innovation impact in services enterprises is expressed as weighted average of individual values of enterprise responses. Maximum values of innovation intensity impact can be monitored in the areas of employees, customers and performances (Table 2).

Gazelles of business services present the most significant impact of innovations in the following areas: new clients, increased revenues from sales, increased customer satisfaction and long-term relationship with customers, tailor-made customer offers, higher labour efficiency, employee satisfaction, and integrated customer information.

\section{Conclusions}

Gazelles do not only bring innovation, but their growth of production is based on the ability to promote innovation and also the effective use of human resources and their creativity. Research results show that the most important share of the total number of enterprises in the observed countries according to the indicator of employment and revenues increase were reached by gazelles in Slovakia. Based on the observation of sectoral structure of Slovak gazelles, we can say that these are marked by dominant existence in the services sector (app. $70 \%$ ). Business services have an important position in the services sector and within them the knowledgeintensive business services linking knowledge and innovation with performance of economy and employment 
The International Journal

ENTREPRENEURSHIP AND SUSTAINABILITY ISSUES

ISSN 2345-0282 (online) http://jssidoi.org/jesi/

2018 Volume 5 Number 3 (March)

http://doi.org/10.9770/jesi.2018.5.3(3)

growth. Their production, as well as production of gazelles of business services is a source of sustainability in the whole economy.

Gazelles of business services in Slovakia are to a large extent technological, as well as non-technological innovations, most of them (93\%) apply at least one type of innovation. All gazelles of foreign origin introduced technological innovation into the business activities of the enterprise, and process innovations to the full extent. This confirmed the importance of an effective use of available human resources, as well as intangible assets in business services, such as ICT. The presumption that service enterprises use as a priority technological innovations was therefore not confirmed.

The results of research, however, show a poor initiative or ability of management of Slovak gazelle within business services to identify the innovation influence on their performance and employment. There is a different situation with foreign gazelles of business services operating in the Slovak market, most of them have expressed a positive effect of innovation on the economic growth of their enterprise. From the aspect of innovation impact on business processes, gazelles emphasized the areas of human resources (staff, customers) and performances. The result shows the significant importance of the business ability to introduce innovation in an optimal way and to prepare stimulating innovative environment. Management of innovations can thus be described as a decisive factor for innovation success expressed by innovation effects.

Innovation activity of gazelles of business services in the Slovak Republic, however, does not primarily only bring the current economic benefits generated by the economic force of these entities. Relevant facts in the area of their social and economic impacts are the facts that are tied to their emergence and that document a unique business plan, new links, innovative solutions and the ability to take risks. These new enterprises with a high economic growth create demand for innovative products in the local economy generated by innovation of their production. They thus create the business environment toward innovations, lay new requirements on the labour force and change clients' expectations. They put pressure on the whole value chain in the local economy toward the acceptance of innovations. Besides creating new jobs and economic benefits, the main social significance of gazelles is clearly their contribution to the change of enterprise philosophy and the society as a whole toward sustainable growth.

\section{Acknowledgements}

Grant project of the Ministry of Education, Science, Research and Sport of the Slovak Republic KEGA 027EU-4/2016 Textbook Business Fundamentals. Project period: 2016-2017.

\section{References}

Aslesen, H. W.; Isaksen, A. 2007. New Perspectives on knowledge-intensive services and innovation, Geografiska Annaler: Series B, Human Geography 89: 45-58. https://doi.org/10.1111/j.1468-0467.2007.00259.x

Barnard, P.; Fischer, E.; Reuber, R.; Rumald, R. 1998. Elusive Gazelles. Finding Them and Helping Them Grow. Summary of a think tank organised by Fulcrum Partners. 


\section{The International Journal}

ENTREPRENEURSHIP AND SUSTAINABILITY ISSUES

ISSN 2345-0282 (online) http://jssidoi.org/jesi/

2018 Volume 5 Number 3 (March)

http://doi.org/10.9770/jesi.2018.5.3(3)

Becchetti, L.; Trovato, G. 2002. The determinants of growth for small and medium sized firms. The role of the availability of external finance, Small Business Economics 19(4): 291-302. https://art.torvergata.it/retrieve/handle/2108/163/4749/148.pdf

Bessant, J.; Tidd, J. 2011. Innovation and Entrepreneurship. 2nd ed. Chichester: John Wiley \& Sons.

Birch, D. L.; Haggerty, A.; Parsons, W. 1997. Who's Creating Jobs? Hot Industries. Cambridge, Massachutts, MA: Cognetics Inc.

Birch, D. L. 1979. The Job Generation Process. MIT Program on Neighborhood and Regional Change. Cambridge, MA: Massachusetts Institute of Technology.

Brynjolfsson, E. 1993. The productivity paradox of information technology, Communications of the ACM 36(12): 66-77. http://ccs.mit.edu/papers/CCSWP130/ccswp130.html

Canab, P. 1998. What's a Gazelle? The Economic Development Marketing Letter 28. February 1998 1(2) Special Edition. Available on the Internet: http://www.blanecanada.com/pdf/WhatsAGazelle.pdf.

Capelleras, J. L.; Greene, F. J. 2008. The determinants and growth implications of venture creation speed, Entrepreneurship and Regional Development 20(4): 317-343. https://www.tandfonline.com/doi/abs/10.1080/08985620701855683

Coad, A. 2009. The Growth of Firms: A Survey of Theories and Empirical Evidence. Cheltenham: Edward Elgar.

Cooper, R. G.; Kleinschmidt, E. J. 1995. Benchmarking the firm's critical success factors in new product development, Journal of Product Innovation Management 12: 374-391.

Cunneen, D. J.; Meredith, G. G. 2007. Entrepreneurial Founding Activities that Create Gazelles, Small Enterprise Research, Taylor \& Francis Online 15(1): 39-59. https://doi.org/10.1080/13215906.2007.11005831

Czarnitzki, D.; Spielkamp, A. 2003. Business services in Germany: bridges for innovation, The Service Industries Journal 23(2): 1-30. https://doi.org/10.1080/02642060412331300862

De Jong, J.; Marsili, O. 2006. The fruit flies of innovations: A taxonomy of innovative small firms, Research Policy 35(2): $213-229$. https://doi.org/10.1016/j.respol.2005.09.007

Dobbs, M.; Hamilton, R. T. 2007. Small business growth: recent evidence and new directions.International, Journal of Entrepreneurial Behaviour \& Research 13(5): 296-322. https://doi.org/10.1108/13552550710780885

Drieniková, K.; Kašt’áková, E. 2016. Význam krajín spoločenstva nezávislých štátov pre strategické rozvojové zámery EÚ [The importance of the Commonwealth of Independent States for the EU's strategic development goals]. Bratislava: EKONÓM.

Eurostat - OECD. 2007. Manual on Business Demography Statistics. Luxembourg: Office for Official Publications of the European Communities. Available on the Internet: http://ec.europa.eu/eurostat/documents/3859598/5901585/KS-RA-07-010-EN.PDF/290a71ec7a71-43be-909b-08ea6bcdc521?version=1.0.

Froehle, C. M.; Roth, A. V. 2004. New measurement scales for evaluating perceptions of the technology-mediated customer service experience, Journal of Operations Management 22 (1): 1-21. https://doi.org/10.1016/j.jom.2003.12.004

Fuller, J.; Matzler, K. 2007. Virtual product experience and customer participation - A chance for customer-centred, really new products, Technovation 27(6): 378-387. https://doi.org/10.1016/j.technovation.2006.09.005 
The International Journal

ENTREPRENEURSHIP AND SUSTAINABILITY ISSUES

ISSN 2345-0282 (online) http://jssidoi.org/jesi/

2018 Volume 5 Number 3 (March)

http://doi.org/10.9770/jesi.2018.5.3(3)

Grundström, Ch.; Sjöström, R.; Uddemberg, A.; Rönnbäck, A. 2012. Fast-Growing SMEs and the Role of Innovation, International Journal of Innovation Management 16(3): 1240003-1-1. Available on the Internet: https://www.iei.liu.se/indek/utbildning/industriellekonomi/teie06/lastips/1.527751/Christinaetal-Fast-growingSMEsandtheroleofinnovation.pdf.

Haataja, M.; Okkonen, J. 2004. Competitiveness of Knowledge Intensive Services. Available on the Internet: www.ebrc.fi/kuvat/255266_04.pdf str. 257

Henrekson, M.; Johansson, D. 2010. Firm growth, institutions and structural transformation, in Fritsch, M. Handbook of research on entrepreneurship and regional development: National and regional perspectives. New York: Edwar Elgar.

Hertog, P. 2000. Knowledge-intensive Business Services as co-producers of innovation, International Journal of Innovation Management 4: 481-528.

Hilkevics, S.; Hilkevica, G. 2017. New information technologies use for Latvian stock companies financial health evaluation, Entrepreneurship and Sustainability Issues 5(2): 178-189. https://doi.org/10.9770/jesi.2017.5.2(1)

Hipp, Ch. 1999. Knowledge-intensive business services in the new mode of knowledge production, AI \& Society 13: 88-106.

Koch, A.; Strotmann, H. 2008. Absorptive capacity and innovation in the knowledge-intensive business service sector, Economics of Innovation and New Technology 17(6): 511-531. http://www.tandfonline.com/doi/abs/10.1080/10438590701222987

Krošláková, M.; Kubičková, V.; Jurkovičová, L.; Kubiniy, N. 2015. Dynamics of high growth enterprises - "gazelles" - in Czech Republic, Business Perspectives 13( 2): 27-35. Available on the Internet:

http://businessperspectives.org/journals_free/ppm/2015/PPM_2015_02_Kroslakova.pdf

Kuo, D. C. L.; Chao, CH. Y. 2014. Exploring the relationships amongst patterns, information technology, and performance in SME-based service innovation, International Journal of Electronic Business Management 12(2): 102-111. https://pdfs.semanticscholar.org/efcc/0bb097f8598d3192c083086433d7a6b12dd3.pdf

Laforet, S. 2010. Managing Brands - A Contemporary Perspective. Maidenhead: McGraw-Hill.

Luhn, A.; Aslanyan, S.; Leopoldseder, C.; Priess, P. 2017. An evaluation of knowledge management system's components and its financial and non-financial implications, Entrepreneurship and Sustainability Issues 5(2): 315-329. https://doi.org/10.9770/jesi.2017.5.2(11)

Mason, G.; Bishop, K.; Robinson, C. 2009. Business growth and innovation: The wider impact of rapidly-growing firms in UK cityregions. London: NESTA.

Miles, I. at al. 1995. Knowledge-Intensive Business Services: Users, Carriers and Sources of Innovation. EIMS Publication

Moreno, A. M.; Casillas, J. C. 2000. High-growth enterprises (gazelles): a conceptual framework. Stockholm, SE: Paper presented at the International Conference of the European Academy of Management (EURAM). Available on the Internet:

https://www.researchgate.net/publication/228926656_High-growth_enterprises_Gazelles_A_conceptual_framework.

Moreno, A. M.; Casillas, J. C. 2007. High-growth SMEs versus non-high-growth SMEs: a discriminant analysis, Entrepreneurship and Regional Development 19(1): 69-88. https://doi.org/10.1080/08985620601002162

Newey, L. 2010. Wearing different hats: How absorptive capacity differs in open innovation, International Journal of Innovation Management 14 (4): 703-731. https://doi.org/10.1142/S1363919610002830

OECD. 2012. Entrepreneurship at a Glance 2012. Paris: OECD Publishing. Available on the Internet: http://dx.doi.org/10.1787/entrepreneur aag-2012-en. 
The International Journal

ENTREPRENEURSHIP AND SUSTAINABILITY ISSUES

ISSN 2345-0282 (online) http://jssidoi.org/jesi/

2018 Volume 5 Number 3 (March)

http://doi.org/10.9770/jesi.2018.5.3(3)

OECD. 2013. Entrepreneurship at a Glance 2013. Paris: OECD Publishing. Available on the Internet: http://www.oecd-

ilibrary.org/industry-and-services/enterpreneurshio-at-a-glance-2013_entrepreneur_aag-2013-en

OECD. 2015. Entrepreneurship at a Glance 2015. Paris: OECD Publishing. Available on the Internet: http://dx.doi.org/10.1787/entrepreneur_aag-2015-en

Ortega-Agilés R. at al. 2009. R\&D Intensive SMEs in Europe: What do we know about them?, IPTS Working Paper On Corporate R\&D and Innovation. No.15.

Raymond, L.; S t-Pierre, J. 2010. R\&D as a determinant of innovation in manufacturing SMEs: An attempt at empirical clarification, Technovation 30(1): 48-56. http://dx.doi.org/10.1016/j.technovation.2009.05.005

Solow, R. M. 1987. We'd better watch out. New York: Times Book Review.

Stone, A.; Badawy, T. L. 2011. SME Innovators and Gazelles in MENA - Educate, train, certify, compete!. World Bank. Available on the Internet:

https://openknowledge.worldbank.org/bitstream/handle/10986/10867/645020BRI0MENA00Box0361538B0PUBLIC0.pdf?sequence=1.

Storey, D. J.; Greene, F. J. 2010. Small Business and Entrepreneurship. Harlow: Pearson Education Limited.

Strerlacchini, A. 1999. Do innovative activities matter to small firms in non-R\&D intensive industries?, Research Policy, $28: 819-832$.

Toivonen, M. 2004. Foresight in services: possibilities and special challenges, The Service Industries Journal, 24(1): 79-98. https://www.tandfonline.com/doi/abs/10.1080/02642060412331301142

Tomlinson, M. 1999. The learning economy and embodied knowledge flows in Great Britain, Journal of Evolutionary Economics 9(4): 431-451. https://link.springer.com/article/10.1007/s001910050090

Verhees, F. J. H. M.; Meulenberg, M. T. G. 2004. Market orientation, innovativeness, product innovation, and performance in small firms, Journal of Small Business Management 42(2): 134-154. https://doi.org/10.1111/j.1540-627X.2004.00102.X

Wilson, D. 1993. Assessing the impact of information technology on organizational performance. in Banker, R.; Kauffman, R.; Mahmood, M. A. (Ed.). Strategic Information Technology Management. Harrisburg, PA: Idea Group.

Wilson, D. 1995. IT investment and its productivity effects: An organizational sociologist's perspective on direction for future research, Economic Innovation and New Technology 4(3): 235-251. https://doi.org/10.1080/10438599500000005

Dana BENEŠOVÁ ORCID ID: https://orcid.org/0000-0002-9336-7447

Viera KUBIČKOVÁ

Anna MICHÁLKOVÁ

Monika KROŠLÁKOVÁ

Register for an ORCID ID:

https://orcid.org/register

Copyright (C) 2018 by author(s) and VsI Entrepreneurship and Sustainability Center

This work is licensed under the Creative Commons Attribution International License (CC BY).

http://creativecommons.org/licenses/by/4.0/

C. (†) Open Access 